\title{
Perception about God and Religion within the Malaysian Society
}

\author{
Mohd Arip Kasmo 1 \\ Abur Hamdi Usman ${ }^{\star}$ \\ Zulkifli Mohamad1 \\ Nasruddin Yunos 1 \\ Wan Zulkifli Wan Hassan ${ }^{1}$ \\ ${ }^{1}$ Centre For General Studies, The National University of Malaysia, Malaysia \\ 2Department of Theology and Philosophy, Faculty of Islamic Studies, The National University of Malaysia \\ *Corresponding Author Email: aburhamdiusman@yahoo.com
}

\section{Doi:10.5901/mjss.2015.v6n1s1p246}

\section{Abstract}

The study reports the finding of a study conducted on 1800 respondents on the issue of believing in god and religion. The study was conducted throughout Malaysia involving male and female respondents between the age of 18 to 50 from the different ethnics and religious groups. Each respondent was given a booklet containing questionnaire containing the statement on the issues of the belief in god and religion. The statements were provided with five choice of responses ranging from 1 (strongly agree), 2 (agree), 3 (not sure), 4 (disagree) and 5 (strongly disagree). The data was analysed using the SPSS to obtain the mean of all the responses, the mean based on the religious group, the percentage of all responses, the percentages of the responses based on the religious group. The data was also analysed using the t-test to see the significant difference of the mean. The finding shows that in general the respondents have a strong belief in religion and god, but when the data was analysed according to the ethnic groups, there finding show that there was significant different between the strength of belief between different ethnic group.

Keywords: Society, perception, God, Religion, Malaysia.

\section{Introduction}

The Malaysian society is a diverse society comprising different ethnic and religious group. The different ethnic groups are also identified with the religious belief. The Malays are mostly Muslim, the Chinese are mostly Buddhists, Taoists, ancestor worshippers or smaller percentages are Christian (DeBernadi, 2004) while the Indian are mostly Hindus (Kent, 2005). In the Malaysian society, the different ethnics do have different perception of god, with the Malay who are Muslim believe in one god, and the Indian who are mostly Hindu believe in one god but manifested in variety of semi gods and the Chinese who are mostly believers in the ancestral worship. Belief in the existence of god and religious practice is importance because god and religion provide guides to life especially for ethics and morality though some thinkers believe otherwise and claimed that atheism provide altruistic thinking (Amarasingam, 2010).

In lieu of that, the first pillar of the "The Pillar of the Country" i.e. The Rukun Negara is to believe in the God. However the belief in religion and god is being challenged by materialism culminating in atheism or agnosticism. In Singapore, $17 \%$ of the population did not have any religion (Lai, 2008). Taking into account that the Singapore population is dominated by the Chinese ethnic, with small minority are the Malay (14\%), might reflect the same pattern in Malaysia. With the advent of the internet where religion and atheism are being discussed freely the people might be swayed by the arguments of the atheist leading to disbelief. At the backdrop of this, the study was conducted to know the perception of the people on the belief in God and religion.

\section{Believe in God: A Revisited Study}

Atheism, agnosticism and humanism have flourished since the enlightenment period in Europe and spread all over the world through modernity, which is strengthened by materialism which see the world in term of material only (Zuckerman, 
2009). Therefore, as a society become more modern, so the people tend to be more atheistic (Soo, 2010). According to the Wikipedia, the percentage of atheist population, the highest percentage of atheists are from the communists countries such as China and Cuba, and the people were forced into atheism. In the developed countries which are based on individual freedom, the percentage of atheist population are 25\% in Germany, $27 \%$ in Belgium, $20 \%$ in the United Kingdom, 27\% in Netherland. ${ }^{1}$ In these contact, the believers still outnumbered the non-believers. In the poorer countries, the percentage of the people who do not have any belief in religion or god is smaller, for example in 1.1\% in Bolivia, 1.4 $\%$ in Paraguay and others. Some people claim that in a happier countries, god and religion are not important, on the contrary they are seen as important in the countries where people are less happy.

Study conducted by Gundlach and Opfinger (2011) was focused on the relationship between happiness and religiosity. According to their findings, religious people are happier if they live in a religious society and so are the atheists, if they live in a society in which religion does not play important role. The European Value claimed that the majority of the people believe in the existence of god. In France according to the study, the percentage of the people who do not believe in the existence of god was $15 \% .{ }^{2}$ According to Davie (1994), the trend in the European countries is that people tend to believe in the existence of god but do not affiliate themselves with any religious group and the trend was growing. The study therefore aimed to know the strength of belief in the existence of god and religion among the different ethnics and since the belief in god and religion is one of the main principal of the national ideology of Malaysia (Cheah, 2002), the findings can be used to help the relevant authority to map the actions to be taken.

\section{The Malaysian Society Perception about God and Religion: An Analytical Measurement}

The study was conducted on 1500 respondents, male and female from all over the country. The age of the respondents ranged from 18 years to 45 years with different educational background. Each respondent was given a set of questionnaire containing statements with given choices of responses known as Likert Scale. Likert Scale is used to construct attitude scale and reliable (Domino \& Domino, 2006). These choices of responses were 1 (strongly agree), 2 (agree), 3 (not sure), 4 (disagree), 5 (strongly disagree). Only two statements were analysed and these statements were, firstly: "Everybody should believe in religion", and secondly: "Everybody should believe in the existence of god".

The two statements reflect the perception of the respondents on the importance of religion and the belief in the existence of god. The booklet of questionnaire were collected to be analyzed using the SPSS. The analysis was made to obtain the mean response for all the respondent, the mean responses according to the ethnic, t-test analysis to see the significance difference of the means.

The raw data were analysed using the SPSS. The data were analysed for the descriptive statistics to obtain the percentages, mean, difference of mean. The first analysis was the percentage of the responses. The percentage of the responses for the statement "Every people should believe in religion" is shown in the following tables.

Table 1: The mean response for all the respondents

\begin{tabular}{cccccc}
\hline & $\mathrm{N}$ & Minimum & Maximum & Mean & Std. Deviation \\
\hline Everybody should believe in the existence of god & 2368 & 1.00 & 5.00 & 1.5473 & .90874 \\
\hline
\end{tabular}

Table 1 shows that the mean response for the statement "Everybody should believe in the existence of god" is 1.5473 . The mean falls between the 1 and 2. The mean can be interpreted that the respondents accepted the statement that everybody should believe in the existence of god. In addition, the data was analysed to know the mean responses of the respondents based on their religious background.

Table 2. The mean response according to ethnic

\begin{tabular}{lccc}
\hline Ethnic & Mean & $\mathrm{N}$ & Std. Deviation \\
\hline Malay & 1.3618 & 1642 & .76690 \\
Chinese & 2.2417 & 484 & 1.07553 \\
Indian & 1.4267 & 75 & .88796 \\
Sarawak native & 1.4353 & 85 & .71459 \\
Sabah native & 1.3934 & 61 & .71365 \\
\hline
\end{tabular}

1 See http://en.wikipedia.org/wiki/Demographics_of_atheism

2 See http://www.europeanvaluesstudy.eu/evs/research/themes/religion/s Study 2005-2008 
Table 2 shows that the mean response of the Malay is 1.3618, the Chinese is 2.2417, the Indian 1.4267, the Sarawak native 1.4353 and the Sabah native 1.3934. The mean responses indicate that the Malay respondents strongly agree with the statement, followed closely by the Indian respondents whose mean response is 1.4267.The difference of mean were using the t-test to see if the difference of mean is significant or not. The t-test result is shown in table 3.

Table 3. T-test between the Malay and the Chinese

\begin{tabular}{ccccc}
\hline $\mathrm{F}$ & Sig. & $\mathrm{t}$ & $\mathrm{df}$ & Sig. (2-tailed) \\
\hline 133.382 & .000 & -20.087 & 2124 & .000 \\
& & -16.786 & 634.423 & .000 \\
\hline
\end{tabular}

Table 3 shows that the mean difference between the mean of the Malay respondents and the mean response of the Chinese respondents is significant. The significance value is 0.000 which is smaller than the critical value of 0.05 at the confidence limit of $95 \%$. Further test was conducted to see if the difference of mean between the Malays and the Indian respondents is significant. The result of the test is shown in table 4.

Table 4. The t-test between The Malay and the Indian

\begin{tabular}{ccccc}
\hline $\mathrm{F}$ & Sig. & $\mathrm{t}$ & $\mathrm{df}$ & Sig. (2-tailed) \\
\hline 2.744 & .098 & -.712 & 1715 & .477 \\
& & -.623 & 79.124 & .535 \\
\hline
\end{tabular}

Table 4 shows that the mean difference between the Malay respondents and the Indian respondents is not significant. The significant value (2-tailed) is 0.477 and 0.535 and these values are larger than the critical value of 0.05 at the $95 \%$ confidence limit. The next t-test was between the Indian and the Chinese respondents. The result of the test is shown in table 5.

Table 5. The t-test between The Indian and the Chinese

\begin{tabular}{ccccc}
\hline $\mathrm{F}$ & Sig. & $\mathrm{t}$ & $\mathrm{df}$ & Sig. (2-tailed) \\
\hline 8.974 & .003 & 6.240 & 557 & .000 \\
& & 7.175 & 110.595 & .000 \\
\hline
\end{tabular}

Table 5 shows that the mean difference between the Indian respondents and the Chinese respondents is significant. The significant value (2-tailed) is 0.000 which is smaller than the critical value of 0.05 at $95 \%$ confident limit.

Table 6: Percentage of the response for statement "Every people should believe in Religion"

\begin{tabular}{lcccc}
\hline & Frequency & Percent & Valid Percent & Cumulative Percent \\
\hline Strongly agree & 1035 & 68.5 & 68.5 & 68.5 \\
Agree & 351 & 23.2 & 23.2 & 91.7 \\
Not sure & 65 & 4.3 & 4.3 & 96.0 \\
Disagree & 29 & 1.9 & 1.9 & 97.9 \\
Strongly disagree & 26 & 1.7 & 1.7 & 99.7 \\
\hline
\end{tabular}

Table 6 shows that $68.5 \%$ of the respondents chose response 1 (strongly agree), $23.2 \%$ chose response 2 (agree), $4.3 \%$ of the respondents chose response 3 (not sure), 1.9\% of the respondents chose response 4 (disagree) and $1.7 \%$ of the respondent chose response 5 (strongly disagree). Therefore 91.7 of the respondents accepted the statement, $4.3 \%$ were not sure and 3.5\% did not accept the statement. The pattern of the response could be clearly seen in the following diagram. 


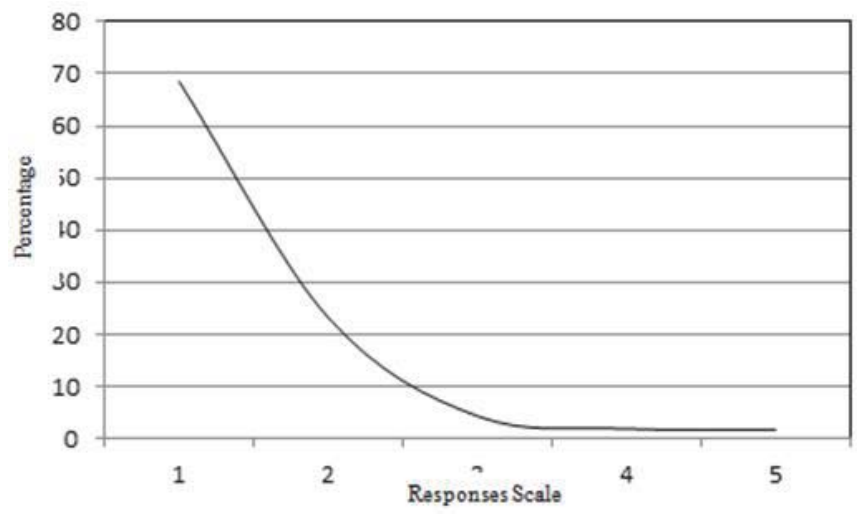

Diagram 1. Percentage Response Curve

Diagram 1 shows that the percentages of the responses declines. The highest response is the first response (strongly agree), followed by the second choice (agree), the next is the third choice which was not sure, then the fourth choice disagree and the last is the fifth choice strongly disagree.

The data were analysed to identify the response according to the ethnic groups i.e. the Malays, the Chinese, the Indian, the Native of Sarawak and the Native of Sabah. The percentages of the responses are shown in the table 7.

Table 7: The Percentage of Responses According to The Ethnic Group.

\begin{tabular}{lcc|cc|cc|cc|cc}
\hline & \multicolumn{2}{c}{ Malay } & \multicolumn{2}{c}{ Chinese } & \multicolumn{2}{c}{ Indian } & \multicolumn{2}{c}{ Sarawak Native } & \multicolumn{2}{c}{ Sabah Native } \\
\hline & Freq & $\%$ & Freq & $\%$ & Freq & $\%$ & Freq & $\%$ & Freq & $\%$ \\
\hline Strongly agree & 807 & 76.6 & 107 & 38.8 & 34 & 70.8 & 35 & 60.3 & 43 & 71.7 \\
Agree & 208 & 19.8 & 105 & 38.0 & 10 & 20.8 & 15 & 25.9 & 11 & 18.3 \\
Not Sure & 18 & 1.7 & 39 & 14.1 & 1 & 2.0 & 4 & 6.9 & 3 & 5.0 \\
Disagree & 4 & 0.4 & 18 & 6.5 & 2 & 4.2 & 3 & 5.2 & 2 & 3.3 \\
Strongly disagree & 16 & 1.5 & 7 & 2.5 & 1 & 2.0 & 1 & 1.7 & 1 & 1.7 \\
\hline
\end{tabular}

Table 7 shows the percentages of the responses according to the different ethnic group. The percentage for the Malay respondents is strongly agree is $76.6 \%$, agree $19.8 \%$, not sure is $1.7 \%$, disagree $0.4 \%$ and strongly disagree is $1.5 \%$. The percentages of the responses are shown in the following diagram.

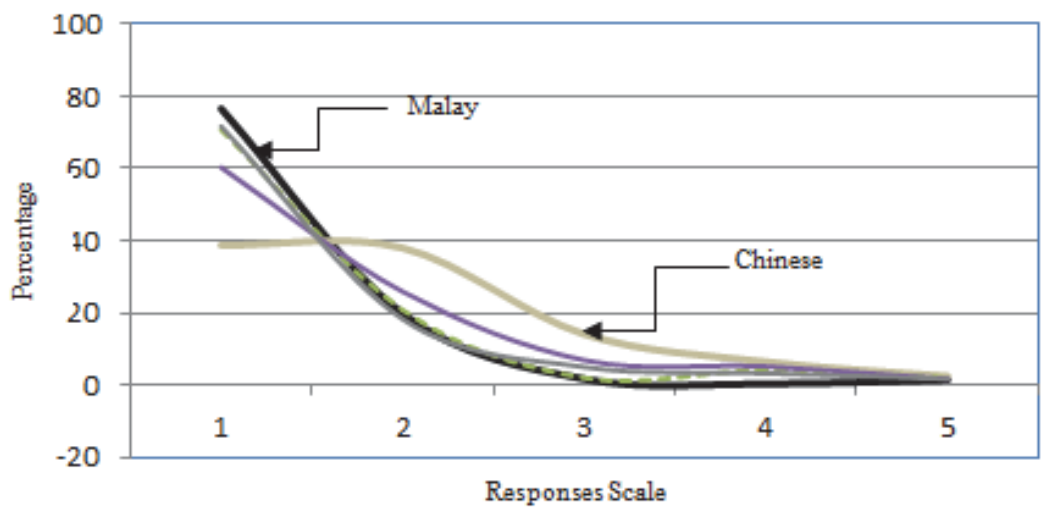

Diagram 2. The percentages curve of the responses according to the ethnic group.

The diagram 2 shows the curves indicating the responses of the different ethnic groups on the statement "Every people should believe in the existence of god". 
Table 8: The Percentages of the Responses According To The Ethnic Group

\begin{tabular}{lcccccccccc}
\hline & \multicolumn{3}{c}{ Malay } & \multicolumn{2}{c}{ Chinese } & \multicolumn{2}{c}{ India } & \multicolumn{2}{c}{ Sarawak Native } & \multicolumn{2}{c}{ Sabah Native } \\
\cline { 2 - 12 } & Freq & $\%$ & Freq & $\%$ & Freq & $\%$ & Freq & $\%$ & Freq & $\%$ \\
\hline Islam & 1054 & 100 & 2 & 0.7 & 1 & 2 & 13 & 22 & 25 & 41.7 \\
Buddha & 0 & 0 & 209 & 75 & 0 & 0 & 0 & 0 & 4 & 6.7 \\
Hindu & 0 & 0 & 1 & 0 & 41 & 85 & 0 & 0 & 1 & 1.7 \\
Christian & 0 & 0 & 54 & 19 & 6 & 13 & 45 & 78 & 30 & 50.0 \\
No religion & 0 & 0 & 7 & 2.5 & 0 & 0 & 0 & 0 & 0 & 0 \\
Free thinker & 0 & 0 & 3 & 1 & 0 & 0 & 0 & 0 & 0 & 0 \\
\hline Total & 1056 & 100 & 278 & 100 & 48 & 100 & 58 & 100 & 100 & 0 \\
\hline
\end{tabular}

Table 8 shows that all Malays respondents are Muslim, $0.7 \%$ of the Chinese respondents are Muslim, $75 \%$ are Buddhists, 19\% are Christian, $2.5 \%$ are not affiliated to any religion and 1\% free thinkers. The Indian, $2 \%$ are Muslim and $85 \%$ are Hindu and $13 \%$ are Christian. From the data, 3.5\% of the Chinese respondents do not have any religion.

\section{Do we Really Belief in the Existence of God?}

The statement which was given to the respondents was "Every people should believe in the existence of god". Although the statement did not ask directly whether the respondents believe in the existence of god, the statement was inclusive of the respondent himself or herself. The following table 9 shows the percentages of the response

Table 9. The Percentages of The Responses

\begin{tabular}{lcccc}
\hline & Frequency & Percent & Valid Percent & Cumulative Percent \\
\hline Strongly agree & 930 & 61.5 & 61.5 & 61.5 \\
Agree & 431 & 28.5 & 28.5 & 90.1 \\
Not sure & 92 & 6.1 & 6.1 & 96.2 \\
Disagree & 34 & 2.3 & 2.3 & 98.4 \\
Strongly disagree & 18 & 1.2 & 1.2 & 99.6 \\
\hline
\end{tabular}

Table 9 shows that $61.5 \%$ of the respondents strongly agree with the statement, $28.5 \%$ agree, $6.1 \%$ were not sure, $2.3 \%$ disagree and $1.2 \%$ strongly disagree. Thus, the percentages of the responses were plotted into curve graph and are shown into the following diagram.

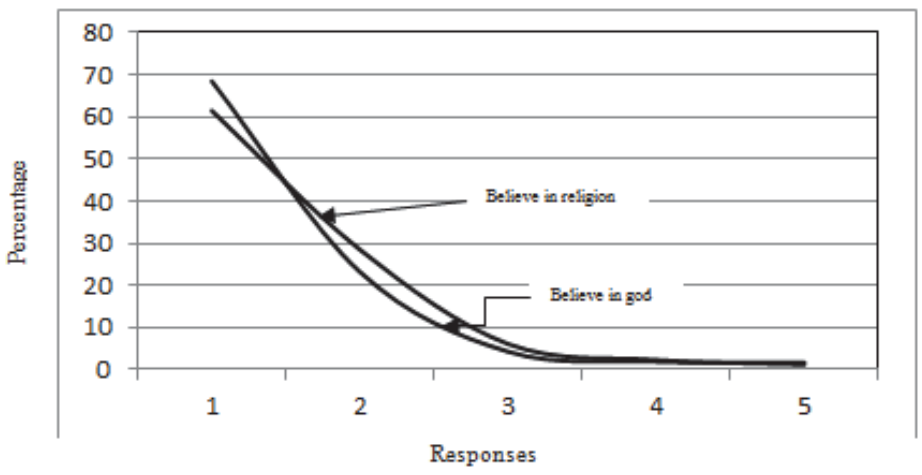

Diagram 3. Percentages curves for the statement "Everybody should belief in the Existence of God and everybody should believe in religion"

Diagram 3 shows the curves of percentages of the responses for the statement "Everybody should believe in a religion' and 'Everybody should believe in the existence of god". The curves show that the patterns of acceptance are almost similar for both statements. Likewise, the data were also analysed according to the ethnic groups to see the pattern of the 
responses. The result is shown in the following table.

Table 10. The percentages according to the ethnics groups

\begin{tabular}{lcccccccccc}
\hline & Malay & \multicolumn{2}{c}{ Chinese } & \multicolumn{2}{c}{ India } & \multicolumn{2}{c}{ Sarawak Native } & \multicolumn{2}{c}{ Sabah Native } \\
\hline & \multicolumn{2}{c}{$\%$} & \multicolumn{1}{c}{$\%$} & \multicolumn{2}{c}{$\%$} & \multicolumn{2}{c}{$\%$} & $\%$ \\
\hline Strongly agree & 736 & 69.7 & 77 & 27.7 & 37 & 77.1 & 35 & 60.3 & 37 & 61.7 \\
Agree & 271 & 25.7 & 111 & 39.9 & 7 & 14.6 & 21 & 36.2 & 18 & 30.0 \\
Not sure & 27 & 2.6 & 59 & 21.2 & 3 & 6.2 & 0 & 0.0 & 3 & 5.0 \\
Disagree & 7 & 0.7 & 23 & 8.3 & 1 & 2.1 & 1 & 1.7 & 2 & 3.3 \\
Strongly disagree & 10 & 0.9 & 7 & 2.5 & 0 & 0.0 & 1 & 1.7 & 0 & 0.0 \\
\hline
\end{tabular}

Table 10 shows the percentage of the responses for the different ethnics group. The percentages of the responses are different for the different ethnics with the Malay, $69.7 \%$ strongly agree to the statement that "Everybody should believe in the existence of god", the Indian $77.1 \%$ strongly agree to the statement, Native of Sarawak $60.3 \%$ and Native of Sabah $61.7 \%$. Only $37 \%$ of the Chinese respondents strongly agree to the statement. The percentages of the responses are plotted into the line graph as shown in diagram 4.

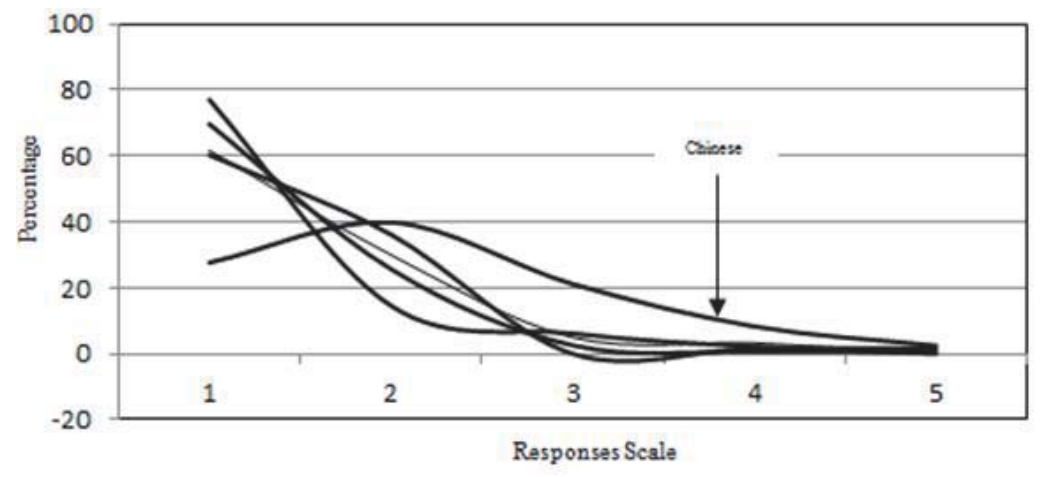

Diagram 4. Line graph for the percentages of the responses according to the ethnic group.

Diagram 4 shows the percentages of responses according to the ethnic groups. The curves show similar pattern of curves except for the Chinese ethnic group, showing again that the Chinese respondents' belief on the existence of god differs from the rest of the other ethnic respondents. The acceptances of the "Believe in religion" and "Believing in the existence of god" among the Chinese respondents are also difference.

\section{The Findings and Conclusion}

The findings of the study indicate that respondents in general accepted that everybody should believe in the existence of God. However when the analysis was further conducted based on ethnic background, it was discovered that the Malay ethnic showed stronger belief in the existence of the god, as seen from Table 2. Followed by the Indian ethnic and the Native of Sarawak and the Chinese ethnic has the weakest belief in the existence of god.

The Malays are mostly Muslim, the Indian are mostly Hindu while the Chinese are mostly traditional believers who worship the ancestors. Naturally the Chinese does not seem to have a strong belief in the existence of the God (Shook, 2010). The finding of the study has also affirmed the finding of the study conducted by The Wall Strait Journal which showed the Muslim in Southeast Asia is the most devout in the world. The Malays undergone religious education, formally in the primary level as well as the secondary school in all the government run schools. This has probably contributed to the stronger belief in the existence of the god. The Hindu on the other hand shows the similar trend as the Muslim in the belief in god (Bellman, 2012). Tarling (1999) claimed that Hinduism in the Southeast Asia was undergoing rejuvenation, which led to stronger belief in the existence of god. Therefore, the finding of the study has also affirmed the assertion that Hinduism was undergoing rejuvenation. 


\section{References}

Amarasingam, A. (2010). Religion and the New Atheism: A Critical Appraisal. Leiden: Koninklijke Brill Nivi.

Bellman, E. (2012). Southeast Asian Muslims Among World's Most Devout. In Wall Strait Journal, August 27.

Cheah, B. K. (2002). Malaysia: The Making of a Nation. Singapore: Institute of Southeast Asian Studies,

Davie, G. (1994). Religion in Britain since 1945: Believing without Belonging. Cambridge: Blackwell.

DeBernardi, J. E. (2004). Rites of Belonging: Memory, Modernity, and Identity in a Malaysian Chinese Community. Stanford: Stanford University Press.

Domino, G. \& Domino, M. L. (2006). Psychological Testing: An Introduction. Cambridge, UK: Cambridge University Press.

Kent, A. (2005).Divinity and Diversity: A Hindu Revitalization Movement in Malaysia. Denmark: NIAS Press.

Lai, A. E. (2008). Religious Diversity in Singapore. Singapore: ISEAS.

Shook, J. R. (2010). The god debate, A 21st century guide for atheist and believer. UK: John Wiley \& Sons LTD.

Tarling, N. (1999). The Cambridge History of Southeast Asia: From World War II to the Present. Cambridge: Cambridge University Press,

Zuckerman, P. (2009). Atheism and Secularity. Santa Barbara, California: Greenwood Publishing.

Soo, P. Y. (2010). The Chinese in God's Land. Pittsburgh: RoseDog Books. 